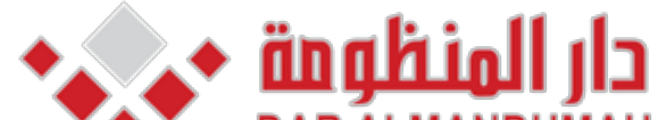 DAR ALMANDUMAH

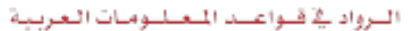

The State of Theoretical Heterogeneity in Management Accounting Research : the Case of Modern ICT Systems

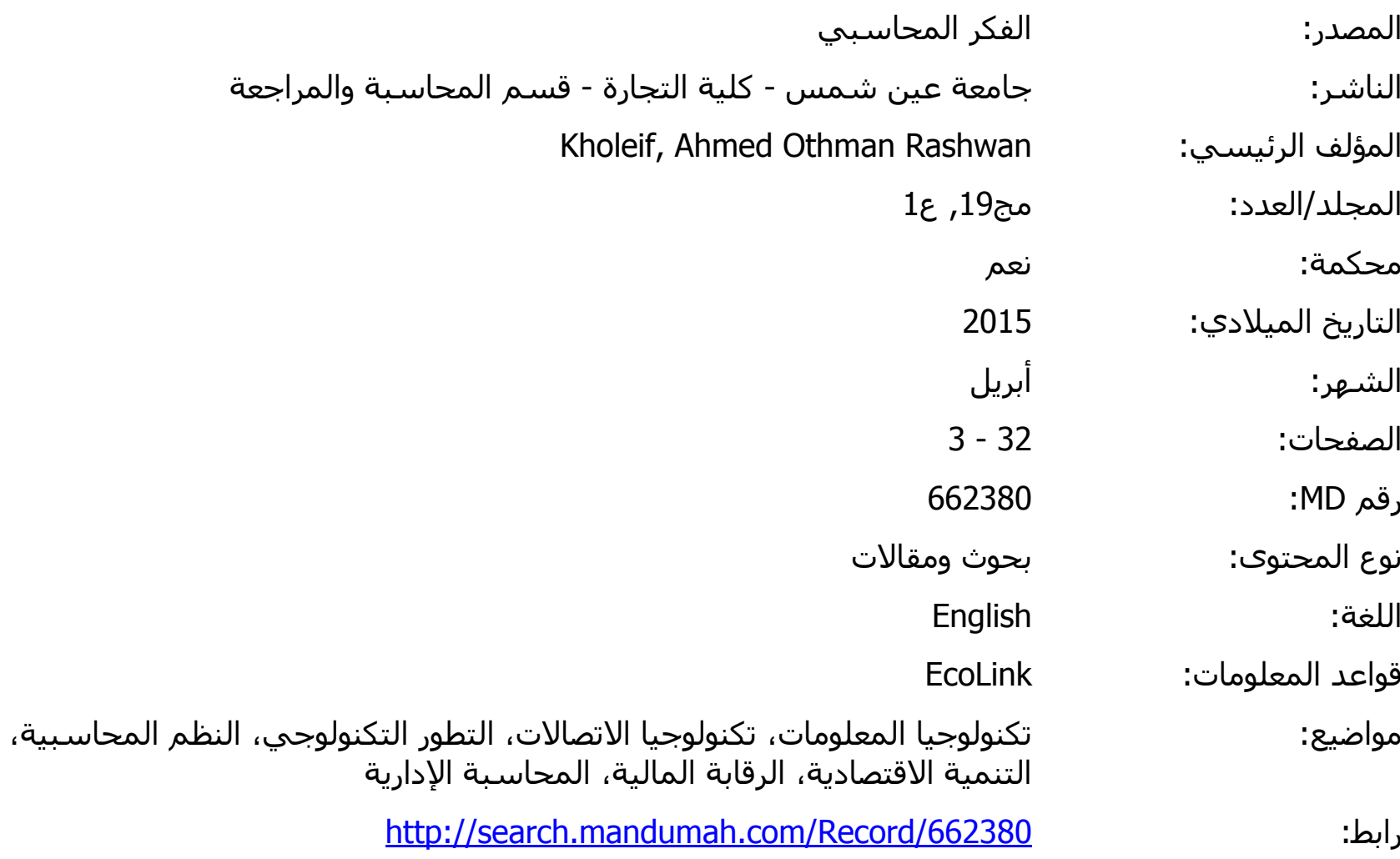

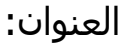




\title{
The State of Theoretical Heterogeneity in Management Accounting Research: The Case of Modern ICT Systems
}

\author{
Dr. Ahmed Othman Rashwan Kholeif
}




\title{
The State of Theoretical Heterogeneity in Management Accounting Research: The Case of Modern ICT systems
}

\author{
Dr. Ahmed Othman Rashwan Kholeif \\ Assistant Professor in Accounting Department of Accounting \\ Faculty of Commerce, Alexandria University
}

\begin{abstract}
Extant management accounting research shows that there is a growing interest into the impact of modern information and communication technology (ICT) on management accounting. In order to advance research within this area, an understanding of the degree of theoretical diversity or heterogeneity in ICT and management accounting practices is of particular importance. The purpose of this paper is to identify the extent and state of heterogeneity in ICT and management accounting research to recommend some guidelines and directions for future research. Findings revealed that research on ICT and management accounting practices has mainly used a wide range of theories imported from other disciplines. Therefore, there is a need for the development of unique theories that explain and predict the potential connections between ICT and management accounting practices. The development of theories that is seen as 'applied' and provides prescriptions for practitioners is also recommended.
\end{abstract}

Keywords: ICT, information and communication technology, management accounting practices, the role of management accountants. 


\section{The State of Theoretical Heterogeneity in Management Accounting Research: The Case of Modern ICT systems}

\section{Introduction}

Modem information and communication technology (ICT) has become one of today's popular integrated information systems in the changing business environment. ICT systems have fundamentally reshaped the way business data is collected, stored, disseminated and used throughout the world (Teittinen et al., 2013). According to Hunton (2002, p. 56), "the blending of ICT and business process integration manifests itself in enterprise resource planning systems". A number of recent studies have investigated the impact of ICT systems on management accounting and control (e.g. Granlund and Malmi, 2002; Scapens and Jazayeri, 2003; Quattrone and Hopper, 2005; Kholeif et al., 2007; Jack and Kholeif, 2008; Hyvonen et al., 2009; Kallunki et al., 2011; Kanellou and Swathes, 2013; Ruivo et al., 2014). In this regard, Chapman (2005, p. 685) argues that studies in this area should view ICT systems not as technological curiosities, but as vehicles through which fundamental questions concerning the nature of management accounting and control may be both asked and answered. In recent years there has been an increasing interest in studying how management accounting practices respond to changes in the business environment (Bums and Scapens, 2000; Chanegrih, 2008; Yazdifar et al., 2008; Johansson and Siverbo, 2009; Wagner et al., 2011; Sanchez-Rodriguez and Sparkman, 2012; Teittinen et al., 2013; Abbasi et al., 2014).

This paper aims to examine the extent and state of diversity in ICT and management accounting research in order to provide directions for future research aiming at explaining and predicting potential connections between ICT and management accounting practices. It focuses on the recent debate around the need for and the degree of theoretical heterogeneity in empirical research in management accounting, the use of the outcome of this debate to assess the state of theoretical heterogeneity in ICT and management accounting practices research and recommendation of future research opportunities to enrich the diversity of theories used to explain and predict the potential connections between ICT and 
management accounting research. Towards this end, the paper is organized as follows. Section 2 presents an overview of the recent debate around theoretical homogeneity or heterogeneity in management accounting research. Based on the outcome of this debate, section 3 assesses the current state of diversity in ICT and management accounting research. In Section 4 a discussion and recommendations for future theorization in research on ICT and management accounting practices are made. Finally, conclusions are drawn in Section 5.

\section{Theoretical Homogeneity or Heterogeneity in Management Accounting}

Debate around theoretical homogeneity or heterogeneity in management accounting research has been initiated by Zimmerman's (2001) commentary on Ittener and Larcker (2001) review and evaluation of management accounting research. Ittener and Larcker use a value-based management framework that incorporates many of the concepts contained in other theories such as contingency theory and economics-based theory to critically review existing empirical research in management accounting that use archival or survey data in examining issues related to the value-based management approach. Based on this review, they identify a number of gaps and inconsistencies that provide opportunities for future research. Ittener and Larcker (2001) observe that empirical management accounting research has failed to accumulate a body of knowledge that builds on previous studies and has left many important issues unresolved. Zimmerman (2001) criticizes the work of Ittener and Larcker (2001) and offers six conjectures to explain the reasons for the failure of management accounting research to produce a cumulative body of knowledge. These conjectures include: the lack of good data like Compustat; atheoretical approach; changing research incentives; the failure to embrace economics as its underlying discipline; few empirically testable theories; and the extensive emphasis on decision making, not control.

To overcome these difficulties, Zimmerman (2001) suggests that management accounting researchers should become more innovative in discovering new interesting data sets. He warn that the shift in research incentives towards more consulting-like, practice-oriented research, will led to less focus on testing and developing theory to explain management accounting practices. Management accounting researchers should develop 
models that result in refutable implications, stop using bad data sets to excuse papers that either do not test hypotheses or test poorly formulated hypotheses and rely more on economics-based hypotheses. Zimmerman (2001) argues that management accountants used to be called controllers. Thus, focusing on decision making and ignoring control will lead to the application of faulty theories to management accounting practices.

In 2002, a special issue entitled 'Debate Forum on Zimmerman's conjectures on management accounting research' is issued by the European Accounting Review to continue scholarly discussion about the issues raised by Ittner and Larcker's (2001) review of empirical management accounting research and Zimmerman's (2001) commentary on Ittner and Larcker's review. Hopwood (2002), Ittner and Larcker (2002), Luft and Shields (2002) and Lukka and Mouritsen (2002) contribute to this debate on the nature and achievements of empirical management accounting research. Hopwood (2002) agrees with many of Zimmerman's (2001) worries about the limitations and dangers of empirical research in management accounting. However, Hopwood (2002) criticizes Zimmerman's (2001) unproblematic optimism in the status and potential of economics-based theory and argues that economics-based theory suffers from many of the same limitations and problems as other social science theories.

Rejecting Zimmerman's (2001) criticisms that empirical management accounting research does not test hypotheses derived from theories and simply describes management accounting practices, Ittner and Larcker (2002) focus on the important role of practice-oriented research in developing and testing economic and non-economic theories. They recommend an integrated theoretical framework that combines economicsbased and behavioural approaches to explain management accounting practices. Luft. and Shields (2002) describe Zimmerman's (2001) conjectures about the unsatisfactory state of empirical management accounting research as inaccurate and misleading. They believe that current research in management accounting is guided by a variety of theoretical frameworks from social sciences such as economics, psychology and sociology that provide more complete explanations of observed management accounting practices. In contrast to Zimmerman's (2001) arguments, Lukka and Mouritsen (2002) argue for heterogeneity in management accounting research as a monolithic economics-based 
paradigm would threatens the ability of management accounting research to develop a critical stance.

The European Accounting Review continues its discussions around Zimmerman's (2001) conjectures on management accounting research. In 2009 , another special issue on 'theorization of management accounting' is launched. In this issue, Malmi and Granlund (2009a, 2009b) and Quattrone (2009) express their views in comment and reply's form. Malmi and Granlund (2009a) argue that there is a need for developing better theories that are unique to management accounting to explain what kind of management accounting systems we should apply, how, in what circumstances, and how to change them as existing theories largely fail to provide valid support for managers, organizations and society. They divide theories currently used and developed into: those theories that have theory status and those theories that do not seem to have theory status. The former is largely imported from other disciplines such as economics, organization theory, sociology and psychology while the latter is not currently regarded as theories by the research community such as activity-based costing, balanced scorecard and value-based management.

In his commentary, Quattrone (2009) shares some of the concerns raised by Malmi and Granlund (2009a) about the current state of empirical management accounting research. However, he criticizes their work because they build their arguments on weak unquestioned assumptions of what is useful to the world of practice. Also, he is not happy with some of definitions provided such as management accounting and theory and states that Malmi and Granlund's (2009a) reference to other disciplines is distracting and makes management accounting research irrelevant. In their reply to Quattrone (2009), Malmi and Granlund (2009b) think that management accounting researchers should stop believing that existing theories such as economics-based theories, contingency theory and social theories, etc provide solutions for current and future challenges facing the management accounting field.

In 2010, Management Accounting Research continues Zimmerman's (2001) debate around the current state of empirical management accounting research and introduces a special section to discuss 'issues in the relationship between theory and practice in. management accounting'. Baldvinsdottir et al. (2010) argue that the conclusions drawn from 
management accounting studies are for further research, rather than for practice. Thus, practical learning from management accounting research has been missing. Seal (2010) examines the impact of management accounting concepts such as return on investment, value-based management and strategic management accounting on practice. He argues that return on investment and value- based management have become part of managerial discourse but strategic management accounting has had a negligible influence on practice. Helden et al. (2010) focus on knowledge creation for management accounting practice in public sector by consultants and academics. They conclude that mutual influences between consultants and researchers are limited.

Another special section in Management Accounting Research in 2010 is related to 'Paradigms in Accounting Research'. Lukka (2010) discuses the roles and effects of paradigms in management accounting research. He criticizes what is perceived to be the increasing narrowness of mainstream management accounting research, especially in the North America and argues for keeping paradigm debates alive. Merchant (2010) criticizes the dominance of empirical tests of economics-based models in the North America and argues that the narrow focus on positivistic topic areas results in the loss of diversity in research topics and methods, which is costly to the U.S. business schools, the academy and society. Malmi (2010) illustrates three of his own experiences, which highlight the dysfunctional effects of paradigmatic borderlines. He argues for multiparadigm openness and new ways forward beyond homogeneity of paradigms. Modell (2010) also finds his cross-paradigm work very challenging and is worried about the high barriers between paradigms. $\mathrm{He}$ approaches the issue of paradigms from the mixed-method perspective to bridge the divide between the functionalist perspective and other alternative interpretive and critical perspectives.

In sum, a single economics-based solution supported by Zimmerman (2001) is totally rejected by many management accounting scholars, arguing for diversity or heterogeneity in (imported or) theories informing management accounting research (Hopwood, 2002; Ittner and Larcker, 2002; Luft and Shields, 2002; Lukka and Mouritsen, 2002; Lukka, 2010; Merchant, 2010; Modell, 2010). The next section assesses the state of theoretical heterogeneity in ICT and management accounting practices in the context, of the above debate. 


\section{Assessment of Theoretical Heterogeneity in Research on ICT and Management Accounting Practices}

Over the years, different theoretical frameworks have been used in studying ICT and management accounting practices. These theories can be classified into a number of research approaches according to their philosophical and theoretical assumptions. For example, Burrell and Morgan (1979) state that 'all theories of organisation are based upon a philosophy of science (the subjective-objective dimension) and a theory of sociology (the regulation-radieal change dimension)'. According to these two dimensions, they classify social and organisational theories into four paradigms [1] that are mutually exclusive; namely functionalist, interpretive, radical humanist and radical structuralist.

Each paradigm has its own ontological, epistemological and methodological positions. Ontology refers to 'the very essence of the phenomenon under investigation' (Burrell and Morgan, 1979: 1). It is concerned with the nature of reality, i.e. whether reality exists as an objective, external, reality or is in fact the product of individual consciousness and hence is subjective. Epistemology is about the grounds or nature of knowledge. It concerns what is accepted as being valid knowledge. Last but not least, methodology focuses on the process of research. It indicates, among others, 'the research methods deemed appropriate for the gathering of valid evidence' (Chua, 1986: 604).

A number of accounting researchers have used Burrell and Morgan's (1979) classification in order to classify accounting theories (e.g. Cooper, 1983; Hopper and Powell, 1985; Chua, 1986). However, they tend to reduce the four paradigms proposed by Burrell and Morgan (1979) into three, namely positivist (or functionalist), interpretive and critical perspectives [2] (e.g. Hopper and Powell, 1985; Chua, 1986; Covaleski et al., 1996). The latter approach focuses on the role of interest, conflicts and unequal distribution of power in providing the potential for radical change while the former two approaches are concerned with the role of regulation, order and stability in explaining why society tends to hold together (Hopper and Powell, 1985: 432). This paper will use this latter classification for management accounting theories. 


\subsection{Positivistic Research on ICT and Management Accounting Practices}

Management accounting researchers became increasingly interested in the positivist approach during the 1970s and 1980s (Ryan et al., 2002). Ontologically, this perspective takes an objective view of social reality, treated the same as the physical or natural world. Researchers, using this approach, believe that the reality exists 'out there' and is independent of the observer. As a result, epistemologically, observable and measurable phenomena can be regarded as valid knowledge about this external reality. Trying to maintain an independent and objective stance, researchers methodologically use the methods applied in the natural sciences to explain and predict social phenomena. Hence, they often use standard research instruments, such as questionnaires, to collect data and analyse these data using statistical techniques to test hypotheses derived from prior theories. This refers to a separation of observations from scientific theories and researchers are expected to add to an existing body of knowledge by acting as remote observers and gathering quantitative data to possibly deduce universal laws to explain and predict social reality.

A set of studies uses a positivistic survey-based approach to identify the impact of ICT on management accounting systems and practices and management accountants' roles and relationships such as Booth et al. (2000), Hyvonen (2003), Spathis and Constantinides (2004), Rom and Rohde (2006), Kallunki et al. (2011), Kanellou and Swathes (2013), Abbasi et al. (2014), Ajit et al. (2014) and Ruivo et al. (2014). Booth et al. (2000) report on the findings of the first quantitative, cross-sectional study on the impact of ICT on accounting in Australian companies. They examine, the degree of information system integration and associated benefits achieved, and the influence of ICT on the use of 'new' management accounting practices. The study is based on a questionnaire survey sent to the Chief Financial Officers (CFOs) of the 800 largest Australian companies, ICT and non-ICT adopters, in 1999. The overall response rate to the survey was $9.25 \%$. The findings of the study indicate that, similar to non-ICT adopters, most ICT adopters report high level of information integration for many functional areas.

These findings also suggest that ICT seems to perform better in transaction processing and ad hoc decision-support than in sophisticated 
decision-support and reporting. It has little impact on the business analysis and decision-support areas of management accounting. Furthermore, Booth et al. (2000) examine whether ICT adopters use more 'new' management accounting practices (e.g. financial and non-financial performance measures, activity-based budgets, customer profitability analysis and valuebased management systems) than non-ICT adopters. The findings of the analysis reveal few differences in the relative use of each of the management accounting practices between ICT and non-ICT adopters. They find that ICT has little impact on the adoption of 'new' management accounting practices.

Hyvonen (2003) compare between ICT and Best of Breed (BoB) adopters regarding the problems perceived in management accounting and the adoption of advanced management accounting techniques such as activity-based costing, target costing, life-cycle costing, activity-based management and balanced scorecard. Industrial business units with at least some degree of ICT were considered ICT adopters while other units using stand-alone systems were considered BoB adopters. The data for the study were gathered through a postal questionnaire addressed to the chief financial officer in 300 large and middle-sized business units in Finland during 1999-2000. The response rate was 33\%. The questionnaire questions dealt with why, by whom and how the IS project (ICT or BoB) has been accomplished, problems perceived in management accounting function and the adoption of modem management accounting techniques.

Findings of the study indicate that financial departments have focused more on traditional BoB systems, while other departments have been more interested in ICT systems. Regarding the problems perceived in management accounting such as problems in measurement and collection of data, problems in cost allocation and problems in common usability of management accounting, results indicate that traditional BoB systems managed better than ICT systems dealing with most of the problems in management accounting. However, the differences between BoB and ICT adopters are not statistically significant. Furthermore, Hyvonen (2003) observes that advanced management accounting techniques are widely adopted in Finnish industrial units but no statistical correlation exists between the adoption of ICT and the use of modern management accounting techniques. 
Spathis and Constantinides (2004) examine the impact of ICT systems on accounting processes to understand why companies in Greece choose to adopt ICT systems and the changes brought in accounting practices. Exploratory interviews with two major ICT vendors and two companies adopting ICT systems were initially conducted. This was followed by choosing a sample of 98 firms and sending a postal questionnaire to 26 companies that agreed to participate in the study. The response rate was $26.5 \%$. The survey results suggest that ICT adoption in Greece was driven by the needs of this increasing competitive environment in order to survive and succeed.

The empirical evidence indicates, that the most popular motives for adopting ICT systems in Greece were the increased demand for real-time information, information for decision making and integration of applications. Also, the adoption of ICT systems in Greece was associated with a number of changes in accounting practices. After ICT implementation, these changes included the increased use of internal audit function, non-financial performance indicators and profitability analyses by business segment and by product. A small proportion of ICT users have adopted a number of more advanced accounting techniques, including activity-based costing and target costing. Spathis and Constantinides (2004) argue that the changes in the accounting processes stem from the main advantages of ICT systems.

Using a survey, Rom and Rohde (2006) examine the relationship between ICT and strategic enterprise management (SEM), on the one hand, and management accounting practices, on the other hand. The focus of the study is on the extent to which ICT vs. SEM systems affect the ability, to solve different management accounting tasks, the data collection vs. reporting and analysis. A survey addressed to the Chief Financial Officer was sent to 3000 Danish companies with more than 50 employees. A total of 349 responses were collected. This represents a response of $11.6 \%$. The data of the study were analysed using linear regression models.

The findings of the study indicate that ICT systems are better than SEM systems in supporting transaction processing and integration but SEM systems are better at supporting reporting and decision-making. Furthermore, advanced management accounting such as non-financial, external and ad hoc management accounting and allocation of costs are 
better supported by SEM systems. Rom and Rohde (2006) conclude that ICT and SEM are complementary systems. Different management accounting tasks are supported by each technology. It seems that ICT systems are the primary enablers of change in transaction processing, while SEM systems are the primary enablers of change in reporting and decisionmaking. Rom and Rohde (2006) recommend considering the potential of closer integration of ICT and SEM system to better serve management accounting tasks.

Kallunki et al. (2011) extend existing research on ICT systems by exploring the effects of ICT system adoption on subsequent non- financial and financial performance of' a firm. Specifically, they investigate the role of formal and informal management control systems as mechanisms which mediate the effect of ICT systems adoption on firm performance. This study is based on survey data drawn from70 Finnish business units. Findings reveal that formal types of management control systems act as intervening variables mediating the positive lagged effect between ICT systems adoption and non-financial performance. Informal types of management control systems, however, do not show similar mediating effects. The study also predict and find a significant relationship between non-financial and financial firm performance. These results indicate that the use of ICT systems results in improved firm performance in the long run, and that more formal than informal types of management controls help firms achieve future performance goals.

Ruivo et al. (2014) empirically measure and analyse the determinants of ICT use and value in a single framework, as well as provide empirical evidence from Portuguese small and medium enterprises (SMEs). Drawing upon the technology-organization-environment framework and the resource-based view, theory and through structural equation modelling, a data set of 134 web-surveyed firms is used to test the hypotheses. The results of the study indicate that compatibility, complexity, best-practices, and efficiency are more important determinants for ICT use as well as training and competitive pressure, suggesting that technological, organizational and environmental characteristics are the main drivers of ICT use among Portuguese SMEs. Similarly, collaboration and analytics are more important for ICT value upon use, suggesting that system capability characteristics are the main drivers of ICT value. ICT value benefits from system enhancements to firms' business processes in the post- 
implementation phases. For Portuguese SMEs the mostly valued metric attained through ICT is management control. Impelled by legislation, Portuguese SMEs are using ICT as the accounting system for management, financial and tax accounting. Portuguese SMEs invest more than $70 \%$ of their annual IT budget to ICT use. Together, these findings offer insights into how Portuguese SMEs use and extract value from ICT, and how enhancements positively impact the system's value. Unlike the typical focus on ICT adoption described in the literature, this research focuses on the post-implementation phase, linking actual use with value creation.

\subsection{Interpretative Research on ICT and Management Accounting Practices}

Unlike the positivistic approach, the interpretive approach is interested in making sense of the social reality through understanding how people understand the behaviour of each other (Puxty, 1993). It focuses on 'the role of language, interpretation, and understanding in social science' (Chua, 1986: 613). From ontological standpoint, the interpretive perspective adopts a subjective view of social reality that considers the world as socially constructed and can only be understood by examining the perceptions of human actors. Therefore, each individual has a unique view of the world that can be partially communicated. In the epistemological view of interpretive approach, researchers interact with that being researched. This epistemology does not try to find generalised explanations or make predictions but instead aims at allowing interpretation and hence, ideally, understanding of particular situations. As Smith (cited in Hussey and Hussey, 1997: 49) put it, '[i]n quantitative research facts act to constrain our beliefs; while in interpretive research beliefs determine what should count as facts.' Methodologically, the interpretive approach normally uses qualitative methods such as in-depth interviews, participative observations, action research, etc. It focuses on small samples, possibly over a period of time.

Institutional theories are mainly used in a number of ICT and management accounting studies to explain the impact of the implementation and use of ICT systems on management accounting practices such as Scapens and Jazayeri (2003), Kholeif et al. (2007), Hyvonen et al. (2009), Sánchez-Rodriguez and Sparkman (2012) and Teittinen et al. (2013). Scapens and Jazayeri (2003) draw on Burns and 
Scapens' (2000) institutional framework to examine the evolutionary processes of management accounting practices following the implementation of a SAP system in BM (Europe), the European division of a large US multinational. A longitudinal case study was used to collect the data for the study. Interviews were conducted with various accounting and non-accounting staff during 1996, 1997, 1998 and 1999. The findings of the study indicate that there were no significant changes to the formal management accounting systems used in BM (Europe) following the ICT implementation. However, there were changes in the role of management accountants. The SAP implementation and use resulted in the elimination of routine accounting jobs, line mangers with accounting knowledge, more forward-looking information and a wider role of management accountants.

The SAP system reduced the routine jobs previously done by management accountants as accounting entries are generated automatically. After the SAP implementation, line managers have performed tasks that have considered management accountants' duties such as monitoring their own budgets, explaining variances and preparing forecasts by themselves. The implementation of the SAP system has also provided more real-time information and more forward-looking forecasts, the beyond budgeting project. As many traditional accounting tasks has been routinized by SAP, management accountants in BM (Europe) are members of cross-functional management teams and help managers interpret the various financial and non-financial information. Scapens and Jazayeri (2003) argue that SAP was not the driver of these changes but its characteristics such as integration, standardization, routinization and centralization facilitated changes that were already taken place.

Kholeif et al. (2007) investigate a detailed case study of management accounting stability due to ICT customization failure in an Egyptian stateowned company (AML) by drawing on new institutional sociology (NIS) theory and its extensions. The research methodology is based, on using an intensive case study informed by NIS, especially the interplay between conflicting institutions, power relations and market forces. Data were collected from multiple sources, including semi-structured interviews, observations, discussions and documentary analysis during 2003-2004. Semi-structured interviews were conducted with the members of the ICT project team, including management accountants, IT staff and line managers. 
The findings of the study reveal that the inability of the ICT system to meet the core accounting requirements of the control authorities (the Central Agency for Accountability) was the explicit reason cited by organizational actors for the failure to embed ICT in AML. In addition, the externally imposed requirements for a uniform accounting system and planning budgets were used to resist both other institutional pressures (the holding company for engineering industries) and market and competitive pressures. Management accountants in AML played a central role in resisting the ICT implementation and contributed to its failure. They used their knowledge with the requirements of the uniform accounting system as a way to resist the ICT implementation. The accounting stability in AML was an outcome and a reason for the ICT customization failure. Under conditions of highly regulated economic and political environment, market and competitive pressures also inhibited the adoption of new, supposedly efficient, accounting systems.

Hyvonen et al. (2009) draw on institutional theory to examine how differences in the accounting-related institutional logics of two case units in the Finnish Defence Forces explain the reactions to external institutional pressures originating from the State Audit Office to change their management accounting systems in the ICT environment. The study draws on recent developments in institutional theory, especially the concept of institutional logic (i.e. the broader cultural beliefs and rules that structure cognition), active agency and the strategic responses to institutional pressures, institutional change and deinstitutionalization and institutional forces and technical forces. The data for the case study consists of project memos and interviews with people involved in designing and implementing ICT - linked cost accounting and reporting systems between 2003 and 2006.

The State Audit Office exerted coercive pressures on the Defence Forces to develop cost accounting practices. These pressures are by nature institutional and relate to legal constraints and requirements, and inspections by authorities to monitor these. The responses to these institutional pressures were different in the two case units but the outcome for management accounting was the same. In the first case, demands for change in management accounting practices were resisted, and in the second case, the old management accounting system was transferred into ICT systems without any significant change in content. These findings can 
be explained by the fact that prevailing institutional logic was such that the uniformed officers were the key persons in all important decisions, accounting or otherwise. Hyvonen et al. (2009) argue that in military organizations, there is a long tradition of dividing the accounting function between accountants and military personnel. Accountants' tasks have traditionally consisted of bookkeeping and financial reporting, while management accounting tasks especially (e.g. planning and control) have been performed predominantly by military personnel, who can be called hybrid accountants.

The existing research in accounting has provided only relatively few empirical findings on the implications for management control when companies implement ERP systems as the technological platform. Especially scarce are the findings concerning the production phase, after implementation, when the information processes, related work practices and the new information contents can be seen as established. Teittinen et al. (2013) explore and theorize the benefits, challenges and problems for management control when an ICT system is in use, four years after the implementation. Findings of the study show why and under what circumstances these challenges and benefits may exist. These results, based on a qualitative case study, are constructed from the viewpoints of people at different levels and functions of the organization. Top management expected a new strategic control system, but due to the many challenges it ended up with merely financial accounting based control. At the operational level, serious challenges lead to inadequate usage of the ICT system. Management control produces the financial basic data and must contend with many practical problems caused by ICT implementation.

\subsection{Critical Research on ICT and Management Accounting Practices}

In the early 1980s accounting researchers have begun adopting different critical theories to examine management accounting practices. In contrast to the functionalist and interpretive perspectives, critical theories explicitly address the issues of conflict, domination and power in their attempt to understand accounting practices (Covaleski et al., 1996). This difference is most evident when classifying research theories using the regulation-radical change dimension of Burrell and Morgan's (1979) classification. However, from the subjective-objective dimension, critical theories ideally have mixed ontological, epistemological and methodological assumptions of 
positivistic and interpretive perspectives. In fact, the critical paradigm comprises both radical structuralism and radical humanism. The former tends to treat the social reality as being composed of external objects independent of any certain person whereas the latter tends to focus on individual perceptions and interpretations (Hopper and Powell, 1985: 451).

Structuration theory is used to inform a few studies on ICT and management accounting such as Caglio (2003) and Jack and Kholeif (2008). Caglio (2003) draw on Giddens' structuration theory to investigate the impact of ICT adoption on the expertise and roles of accountants within an Italian medium-size firm (PHS). The main issues addressed by this case study are whether accountants are likely to expand their activities and competencies in the field of business and IT or line managers and IT specialists are going to broaden their roles and expertise in the traditional preserve of accountants. The potential change in the expertise and roles of accountants is conceptualised as a structuration process, and ICT systems as modalities of structuration which influence the direction of hybridization between accountants and other professional groups. In-depth semistructured interviews with accountants, managers, IS and line people involved in the implementation of the new ICT system were conducted during 1999- 2000.

The findings of the study suggest that the new ICT system has led to more standardized accounting practices, a stronger need for integration and cross-functional collaboration and a more significant role of accounting department in managing the new ICT system. Accountants at PHS have experienced a phenomenon of hybridization due to the ICT implementation because IS professionals and line people has started to use accounting information and the boundaries between financial and management accounting are becoming less clear. The ICT implementation has emphasized the need to work collaboratively and the division of functions has lost its importance. Accountants in the new ICT environment have played a more active role in the maintenance and management of the ICT system and they have become less dependent on IS professionals.

Jack and Kholeif (2008) use strong structuration theory, a reinforced version of Giddens' structuration theory, to explore the conflicting beliefs about the role of management accountants during an attempt to establish an ICT system in an organization (the IMC) jointly funded by the European 
Union (EU) and the Egyptian government. Case study materials were collected during 2003-2005, which included interviews, site visits and observations, correspondence by e-mail across the period and the collection of documentary evidence. The results of the study reveal that the ICT system did not change the accounting systems and practices used in the IMC. On the contrary, it was customised to manage the performance-based budgeting and stability, of some sorts, was achieved. The findings also indicate that there were no changes to the role of management accountants in the IMC following the implementation of the ICT system.

Management accountants in the IMC were in the centre of a three way contest over their roles in the organization. The Financial Controller appointed had as his background the corporate business image (i.e. business integrator and strategic leader), chosen in part because of his industrial and entrepreneurial experience. The EU had adopted the concept of performance-based budgeting in the EMC and was in the transition from requiring the accounting system and personnel to report on the disbursement of funds. The role of management accountants is now modernised to some extent to that of integrator, but not to the extent embodied in the Financial Controller appointed. The Egyptian government advertised for a traditional management controller, a service provider. Despite the forward-looking dispositions of key actors within the IMC and from the EU, the role of management accountants here became compressed to the traditional one of cost information collector and provider.

Actor-network theory is used by a number of scholars to make sense of the impact of ICT on management accounting such as Lodh and Gaffikin (2003), Dechow and Mouritsen (2005), Quattrone and Hopper (2005), Hyvonen et al. (2008) and Wagner et al. (2011). Lodh and Gaffikin (2003) use actor-network theory to investigate the implementation process of a SAP system, including an integrated accounting and cost management system in a world-class organization, a major steel firm (FPD), in Australia. The longitudinal field work was carried out during 1992-94 and included various meetings, review sessions, training courses, project design-related documents, minutes and discussion papers as well as interviews with various levels of people involved in the ICT project. The analysis consists of three episodes. The first episode explains why the possibilities of having an integrated accounting and cost management system emerged. The second episode focuses on the initial trial of a standalone system 
development. The last episode deals with the various events when more actor-networks were involved in the implementation of the integrated accounting and cost, management system using the SAP system.

The findings of the study indicate that the change to the integrated accounting and cost management system as part of the SAP system is not just a constant. It is an outcome of a continuous translation process. Lodh and Gaffikin (2003) argue that the fabrication of the integrated accounting and cost management system had many organizational behavioural implications. The ownership of information by the interested groups could be a kind of power struggle over which the various groups and departments at FPD would have to fight over. In the SAP environment, different hierarchical segments can be used for integrating the sub-systems which can give rise to conflicts amongst various professional groups. It was evident that there would some struggle over accountability amongst various groups after the implementation of the SAP system. Also, the implementation of SAP in FPD created new opportunities and pressures for management accountants such as the need for multidisciplinary knowledge with a cross-functional focus and a change in attitude to managing cost management systems on a real-time basis.

Drawing on Actor-Network Theory and Symbolic Interactionism, Dechow and Mouritsen (2005) investigate the use of ICT systems to integrate management control systems in two firms (TimeCorp and SpaceCorp) in Denmark. Two longitudinal case studies were conducted for about 1 (1/2) year. TimeCorp was one of the World's leading manufacturers of pumps and pumping systems. SpaceCorp was one of the largest industrial groups in Denmark. 34 interviews (16 at Time Corp and 18 at SpaceCorp) were the main data collection method. They conducted in two phases. The first phase focused on the configuration of the ICT systems in the two cases. The second phase focused on the use of these systems for various management control purposes.

The findings of the study reveal that ICT systems incur a techno-logic that conditions how control can be performed through financial and nonfinancial representations. Dechow and Mouritsen (2005) argue that management control in an ICT environment is not a property of the accounting function but a collective affair where management control information is collected by other functions. ICT systems in TimeCorp and 
SpaceCorp have developed alternatives to financial controls based on the logistics structure's operational non-financial data which is more plastic than the accounting structure. This means that traditional management control based on accounting numbers in the ICT setting in both firms has had moderate impact. Also, ICT systems in the two cases have not turned non-accountants into hybrid- accountants but ensured that separate commercial entities have become mutually dependent when one ICT system replaced local systems.

Based on Actor-Network Theory, Quattrone and Hopper (2005) examine the impact of ICT implementation on management control systems in two multinational organizations (Sister Act and Think- Pink). Two case studies were conducted. Sister Act, the first case, was a multinational organization based in Europe, marketing office automation products and sewing machines for industrial and domestic purposes. ThinkPink, the second case, was a large American multinational organization, manufacturing and supplying products for home buildings and composite materials world-wide. Semi-structured interviews (12 at Sister Act \& 6 at Think-Pink) were conducted with managers involved in ICT projects.

The results of the study indicate that, in the first case, ICT was not a vehicle for revolutionary changes to management control systems but was restricted to incrementally improving existing management control practices. In Sister Act, existing distance was maintained and integration was restricted to produce extant hierarchical controls. Stability in conventional accounting controls was maintained. In the second case, the SAP implementation broke down functional areas and distances. Everyone has become a hybrid-accountant and could access and input information from different locations, for different purposes, for different bosses. ICT was used to collapse distance through real-time information in a matrix structure.

Hyvonen et al. (2008) draw on actor-network theory to examine how the implementation of ICT has facilitated management control change, the adoption of $\mathrm{ABC}$ to form a new management control system called virtual integration in a multinational firm (Alpha). The data of the study were collected from people involved in the creation of the new management control system during the period 2002-2005. Two ICT systems, Phoenix and SAP R/3 were used in a project to develop an integrated profitability 
management system throughout all the profit centres of Alpha. Four episodes are used to analyse the empirical data. The first episode maps out the main historical events before the start of the new profitability management system. The second and the third episodes illustrate the actual events relating to the creation of the new system at divisional and mill levels. The last episode deals with events using second-hand knowledge.

The findings of the study indicate that management control change in Alpha was unplanned as none of the actors had a profound understanding of the final outcome. The opportunity for developing the management control system was provided when a new ICT system was implemented. It seems that the technical opportunity to centralize data management through the ICT solution led to the idea of centralizing managementcontrol and the creation of virtual integration. The ICT solution virtually forces management accountants to study the logic of the solution and challenges them to invent ways of combining accounting and management rationalities. Furthermore, the need for comparable mill-level information was critical for initiating the management control change process. After the ABC software had been selected, access to the new profitability information was granted only to top management, while the periphery went on with its traditional reporting.

Wagner et al. (2011) extend existing knowledge on how softwarebased accounting tools might work effectively within an organization. The empirical data is based on events that unfolded following the introduction of a new ICT system at an Ivy League University. The study adopts a practice theory perspective to yield insight into how accounting is made workable when it is entangled with an ICT system. It describes a negotiation process that occurred after roll-out that resulted in a reconfiguration of the ICT to integrate some of the legacy functionalities that were familiar to organizational participants and which were considered by them to provide a more effective way to manage their finances. The contribution of the study is not only to show the importance of such postroll-out modifications for creating a working information system, but also to extend previous studies of non-linear accounting change processes by emphasizing how these modifications are dependent on the particular entanglement of users and technology rather than either features of the technology or the agency of the humans involved. Moreover, the analysis of the case data suggests that management accounting in particular may not 
be easily captured in ICT packages, even where the technology architectures are supposedly designed for a. particular industry. The case data also points to issues of affordability and the power of communities of practice as mediating the extent to which these familiar accounting logics may become integrated within the ICT system.

\section{Discussion and directions for future research}

The debate initiated by Zimmerman's (2001) commentary on Ittener and Larcker's (2001) review and evaluation of management accounting research and subsequent responses from management accounting researchers around the globe highlights the increasing pressures on management accounting research to carefully re-examine its paradigms, assumptions and theories and try to establish links with practices. This debate suggests various alternative solutions as follows: 1) single economics-based, theory vs. multiple theories from different disciplines, and 2) importing theories from other disciplines vs. building unique management accounting theories. Zimmerman (2001) supports a single economics-based solution. Other management accounting researchers argue for diversity or heterogeneity in theories informing management accounting research (Hopwood, 2002; Ittner and Larcker, 2002; Luft and Shields, 2002; Lukka and Mouritsen, 2002; Lukka, 2010; Merchant, 2010; Modell, 2010). Malmi and Granlund (2009a, 2009b) and Malmi (2010) suggest the development of unique management accounting theories. Other management accounting researchers encourage the use of theories from other social sciences to explain management accounting practices (Hopwood, 2002; Ittner and Larcker, 2002; Luft and Shields, 2002; Lukka and Mouritsen, 2002; Lukka, 2010; Merchant, 2010; Modell, 2010).

ICT and management accounting practices have been studied from a variety of research paradigms. Scapens and Jazayeri (2003), Kholeif et al. (2007) and Hyvonen et al. (2009) make use of institutional theory. Caglio (2003) and Jack and Kholeif (2008) draw on structuration theory and a number of researchers (Lodh and Gaffikin, 2003; Dechow and Mouritsen, 2005; Quattrone and Hopper, 2005; Hyvonen et al., 2008; Wagner et al., 2011) draw on actor-network theory. Some exploratory research use a positivistic survey-based approach (Booth et al., 2000; Hyvonen, 2003; Spathis and Constantinides, 2004; Rom and Rohde, 2006; Kallunki et al., 2011; Kanellou and Swathes, 2013; Abbasi et al., 2014; Ajit et al., 2014; 
Ruivo et al., 2014). Future research on ICT and management accounting practices should be aware of the alternatives offered by the debate around theoretical homogeneity or heterogeneity in management accounting research when testing or developing their theories. Unique theories that explain and predict the connections between ICT and management accounting practices should be developed. Possible expansion of theories informing research on ICT and management accounting practices is to import theories from IS research such as punctuated equilibrium theory (Gersick, 1991), organizational knowledge creation (Nonaka, 1994) and organizational learning theory (Huber, 1991).

Another issue that future research on ICT and management accounting practices should take into account is the contributions of their research findings to practice. In this regard, Baldvinsdottir et al. (2010) describe the key stages in empirical management accounting research, namely identification, description, explanation, understanding and prescription. The last stage is the most important stage in linking research to practice. The production of research on ICT and management accounting connections that is seen as 'applied' should provide prescriptions for practitioners. Baldvinsdottir et al. (2010) and Mami and Granlund (2009a) recommend the use of innovative action research to solve practical problems with practitioners and use the novel solutions suggested to create theories useful for practice.

\section{Conclusion}

The objective of this paper was to examine the extent and state of diversity in ICT and management accounting research to recommend some guidelines and directions for future research. To achieve this aim, the paper has covered the recent debate around empirical research in management accounting. The debate around the unsatisfactory state of empirical management accounting research has resulted in offering various future solutions and directions for the theorization of management accounting research, including the sole reliance on economics-based theory, the diverse use of wide range of theories from different disciplines, importing theories from other disciplines or building unique management accounting theories. Research on ICT and management accounting practices has mainly used a wide range of theories imported from other disciplines. However, there is a lack of some attempts to develop unique theories that 
explain and predict the potential connections between ICT and management accounting practices. Another limitation of current ICT and management accounting practices is the need for the development of theories that is seen as 'applied' and provides prescriptions for practitioners

\section{Footnotes}

[1] The term paradigm was introduced by Kuhn (1962: viii) to refer to 'universally recognised scientific achievements that for a time provide model problems and solutions to a community of practitioners'. It provides 'a framework including an accepted set of theories, methods and ways of defining data' (Hussey and Hussey, 1997: 47).

[2] Critical perspectives combine the two radical paradigms.

\section{Appendix (A): List of Journals Reviewed}

Abacus; Academy of Management Review; Accounting Forum; Accounting Horizons; Accounting Review; Accounting, Organizations and Society; Assembly Automation; Australian Accounting Review; British Accounting Review; Business Process Management Journal; California Management Review; Communication of ACM; Critical Perspective on Accounting; European Accounting Review; Education, Business and Society: Contemporary Middle Eastern Issues; Harvard Business Review; Information Technology and People; International Journal of Accounting; International Journal of Accounting Information Systems; International Journal of Accounting \& Information Management; Journal of Accounting and Organizational Change; Journal of Enterprise Information Management; Journal of Information Systems; Journal of International Financial Management and Accounting; Journal of Management Accounting Research; Journal of Strategic Information Systems; Management Accounting (UK); Management Accounting Research; Marketing Review; MIS Quarterly; Organization Science; Production Planning and Control; Qualitative Research in Accounting \& Management; Research in Third World Accounting 


\section{References}

- Abbasi, S., Zamani, M. and Valmohammadi, C. (2014) The effects of ERP systems implementation on management accounting in Iranian organizations, Education, Business and Society: Contemporary Middle Eastern Issues, 7(4), 245 - 256.

- Ajit, D., Donner, H. and Patnaik, S. (2014) ERP system implementation announcements: does the market cheer or jeer the adopters and vendors?, International Journal of Accounting \& Information Management, 22 (4), 339 - 356.

- Baldvinsdottir, G., Mitchell, F. and Norreklit, H. (2010) Issues in the relationship between theory and practice in management accounting, Management Accounting Research, 21 (1): 79-82.

- Booth, P., Matolcsy, Z. and Wieder, B. (2000) The Impacts of enterprise resource planning systems on accounting practices - the Australian experience, Australian Accounting Review, 10 (3), 4-18.

- Burns, J. and Scapens, R. W. (2000) Conceptualising management accounting change: an institutional framework, Management Accounting Research, 11, 3-25.

- Burrell, G. and Morgan, G. (1979) Sociological paradigms and organisational analysis: elements of the sociology of corporate life, London: Heinemann.

- Caglio, A. (2003) Enterprise resource planning systems and accountants: towards hybridization?, The European Accounting Review, 12 (1), 123-153.

- Chanegrih, T. (2008) Applying a typology of management accounting change: a research note, Management Accounting Research, 19, 278-285.

- Chapman, C.S. (2005) Not because they are new: developing the contribution of enterprise resource planning systems to management control research, Accounting, Organizations and Society, 30 (7-8), 685-689.

- Chua, W. F. (1986) Radical developments in accounting thought', the Accounting Review, LXI (4): 601-632.

- Cooper, D. (1983), Tidiness, muddle and things: commonalties and divergences in two approaches to management accounting research, Accounting, Organisations and Society, 8 (2/3): 269- 286. 
- Covaleski, M. A., Dirsmith, M. W., and Samuel, S. (1996) Managerial accounting research: the contributions of organizational and sociological theories, Journal of Management Accounting Research, 8: 1-29.

- Dechow, N. and Mouritsen, J. (2005) Enterprise resource planning systems, management control and the quest for integration, Accounting, Organizations and Society, 30, 691-733.

- Gersick, CJ.G. (1991) Revolutionary change theories: a multi-level exploration of the punctuated equilibrium paradigm, Academy of Management Review, 16(1), 10-36.

- Granlund, M. \& Malmi,. T. (2002) Moderate impact, of ERPs on management accounting; a lag or permanent outcome?, Management Accounting Research, 13, 299-321.

- Helden, G. J., Aardema, H., Bogt, H. J., Groot, T. L. (2010), Knowledge creation for practice in public sector management accounting by consultants and academics: preliminary findings and directions for future research, Management Accounting Research, 21(1): 83-94.

- Hopper, T. M. and Powell, A; (1985) Making sense of research into organisational and social aspects of management accounting: a review of its underling assumptions, Journal of Management Studies, 22 (5): 429-436.

- Hopwood, A. G. (2002), If only there were simple solutions, but there aren't: some reflections on Zimmerman's critique of empirical management accounting research, The European Accounting Review, 11 (4): 777- . 785.

- Huber, G. P. (1991), Organizational learning: the contributing processes and the literatures, Organization Science, 2(1), 88- 115.

- Hunton, J.E. (2002) Blending information and communication technology with accounting research, Accounting Horizons, 16, 5567.

- Hussey, J. and Hussey, R. (1997), Business research: a practical guide for undergraduate and postgraduate students, London: Macmillan Press LTD.

- Hyvonen, T. (2003) Management accounting and information systems: ERP versus BOB, European Accounting Review, 12(1), 155-173. 
- Hyvonen, T., Jarvinen, J. and Pellinen, (2008) A virtual integration the management control system in a multinational enterprise, Management Accounting Research, 19, 45 -61.

- Hyvonen, T., Jarvinen, J., Pellinen, J. and Rahko, T. (2009) Institutional logics, ICT and stability of management accounting, European Accounting Review, 18(2), 241-275.

- Ittner, C. D. and Larcker, D. F. (2001), Assessing empirical research in managerial accounting: a value-based management perspective, Journal of Accounting and Economics, 32: 349-410.

- Ittner, C. D. and Larcker, D. F. (2002), Empirical management accounting research: are we just describing management consulting practice?, The European Accounting Review, 11 (4): 787-794.

- Jack, L. and Kholeif, A. (2008) Enterprise resource planning and a contest to limit the role of management accountants: a strong structuration perspective, Accounting Forum, 32, 30-45.

- Johansson, T. and Siverbo, S. (2009) Why is research on management accounting change not explicitly evolutionary? taking the next step in the conceptualization of management accounting change, Management Accounting Research, 20, 146-162.

- Kallunki, J., Laitinen, E. and Silvola, H. (2011) Impact of enterprise resource planning systems on management control systems and firm performance, International Journal of Accounting Information Systems, 12, 20-39.

- Kanellou, A. and Swathes, C. (2013) Accounting benefits and satisfaction in an ERP environment, International Journal of Accounting Information Systems, 14, 209-234.

- Kholeif, A., Abdel-Kader, M. and Sherer, M. (2007) ERP customization failure: institutionalized accounting practices, power relations and market forces, Journal of Accounting and Organizational Change, 3(3), 250 - 269.

- Kuhn, T. S. (1962), The structure of scientific revolutions, Chicago: University of Chicago Press.

- Lodh, S. and Gaffikin, M. (2003) Implementation of an integrated accounting and cost management system using the SAP system: a field study, European Accounting Review, 12(1), 85 - 121.

- Luft, J. and Shields, M. D. (2002), Zimmerman's contentious conjectures: describing the present and prescribing the future of 
empirical management accounting research, The European Accounting Review, 11(4): 795-803.

- Lukka, K. and Mouritsen, J. (2002), Homogeneity or heterogeneity of research in management accounting, The European Accounting Review, 11 (4): 805-811.

- Lukka, K. (2010), The roles and effects of paradigms in accounting research, Management Accounting Research, 21(1): 110-115.

- Malmi, T. (2010), Reflections on paradigms in action in accounting research, Management Accounting Research, 21(1): 121-123.

- Malmi, T. and Granlund, M. (2009a), In Search of management accounting theory, The European Accounting Review, 18(3): 597620.

- Malmi, T. and Granlund, M. (2009b), Agreeing on problems, where are the solutions? a reply to Quattrone, The European Accounting Review, 18(3): 631-639.

- Merchant, K. A. (2010) Paradigms in accounting research: A view from North America, Management Accounting Research, 21(1): 116120.

- Modell, S. (2010), Bridging the paradigm divide in management accounting research: The role of mixed methods approaches, Management Accounting Research, 21(1): 124-129.

- Nonaka, I. (1994) A dynamic theory of organizational knowledge creation, Organization Science, 5(1), 14-37.

- Puxty, A. G. (1993) The Social and Organisational Context of Management Accounting, London: Academic Press.

- Quattrone, P. (2009) We have never been post-modern: on the search of management accounting theory, The European Accounting Review, 18(3): 621-630.

- Quattrone, P. and Hopper, T. (2005) A 'time-space odyssey': Management control systems in two multinational organizations, Accounting, Organizations and Society, 30, 735-764.

- Rom, A. and Rohde, C. (2006) Enterprise resource planning systems, strategic management systems and management accounting: a Danish study, Journal of Enterprise Information Management, 19(1), 50-66.

- Ruivo, P., Oliveira, T. and Nieto, M. (2014) Examine ERP postimplementation stages of use and value: Empirical evidence from 
Portuguese SMEs, International Journal of Accounting Information Systems, 15, 166- 184.

- Scapens, R. W. and Jazayeri, M. (2003) ERP systems and management accounting change: opportunities or impacts? A research note, the European Accounting Review, 12 (1), 201-233

- Ryan, B., Scapens, R. W. and Theobald, M. (2002) Research method and methodology in finance and accounting, London: Academic Press.

- Sánchez-Rodriguez, C. and Sparkman, G. (2012) ERP systems and management accounting: a multiple case study, Qualitative Research in Accounting \& Management, 9(4), 398 - 414.

- Seal, W. (2010) Managerial discourse and the link between theory and practice: from ROI to value-based management, Management Accounting Research, 21(1): 95-109.

- Spathis, C. and Constantinides, S. (2004) Enterprise resource planning systems' impact on accounting processes, Business Process Management Journal, 10(2), 234-247.

- Teittinen, H., Pellinen, J. and Järvenp, M. (2013) ERP in action Challenges and benefits for management control in SME context, International Journal of Accounting Information Systems, 14, 278296.

- Wagner, E., Moll, J. and Newell, S. (2011) Accounting logics, reconfiguration of ERP systems and the emergence of new accounting practices: A sociomaterial perspective, Management Accounting Research, 22, 181- 197.

- Yazdifar, H., Zaman, M., Tsamenyi, M. and Askarany, D. (2008) Management accounting change in a subsidiary organization, Critical Perspectives on Accounting, 19, 404-430.

- Zimmerman, J. L. (2001) Conjectures regarding empirical managerial accounting research, Journal of Accounting and Economics, 32: 411-427. 